\author{
Леонтісва Софія Леонідівна, ${ }^{a}$ \\ старший викладач кафедри академічного \\ та естрадного вокалу Інституту мистецтв \\ Київського університету імені Бориса Грінченка \\ ORCID 0000-0002-6664-5288
}

\title{
ВОКАЛЬНЕ МИСТЕЦТВО ТА РЕПЕРТУАР У СУЧАСНОМУ КУЛЬТУРОЛОГІЧНОМУ ПРОСТОРІ ЕПОХИ
}

\begin{abstract}
Мета роботи: аналіз стану вокального мистецтва крізь призму репертуару як відображення культуропростору, що сприятиме визначенню концепту репертуару для визначення соціального стану культури епохи. Методологія дослідження: полягає в застосуванні компаративного, історико-логічного методів, а також емпіричних, загальнонаукових (аналіз, синтез) методів. Наукова новизна: В статті зроблено спробу проаналізувати сьогоденний стан вокального мистецтва, а також особливостей репертуарної політики виконавців. Окремо зроблено акцент на формуванні сучасного концепту репертуару. Висновки: музичний репертуар існує в просторі відповідної епохи та $є$ концептуальним зображенням сучасних йому подій та настроїв у соціумі. Водночас саме через вокальне мистецтво, як таке, що пов' язане з вербальною складовою, можливе найбільш повне втілення культуропростору епохи. Вокальне мистецтво як таке, що є позиційно доступним людству та іманентною ознакою архетипів української ментальності, а також надає можливості через підбор репертуару актуалізувати питання меж надіндивідуальним, соціальним, історичним досвідом особистостей в певному полі культури як визначального для детермінування характеру діяльності та пізнання архетипових складових у культуротворчих процесах, які здатні відбивати індивідуально-національний та загальносвітовий контекст.
\end{abstract}

Ключові слова: музичний репертуар, вокальне мистецтво, архетип, українська ментальність.

Леонтиева София Леонидовна, стариий преподаватель кафедры академического и эстрадного вокала Института искусств Киевского университета имени Бориса Гринченко

Вокальное искусство и репертуар в современном культурном пространстве эпохи

Цель работы: анализ вокального искусства сквозь призму репертуара как отражение культуропростору, что будет способствовать определению концепта репертуара для определения социального положения культуры эпохи. Методология исследования: заключается в применении сравнительного, историкологического методов, а также эмпирических, общенаучных (анализ, синтез) методов. Научная новизна: В статье сделана попытка проанализировать сегодняшнее состояние вокального искусства, а также особенностей репертуарной политики исполнителей. Отдельно сделан акцент на формировании современного концепта репертуара. Выводы: музыкальный репертуар существует в пространстве соответствующей эпохи и является концептуальным изображением современных ему событий и настроений в социуме. В то же время именно из-за вокальное искусство, как таковое, что повязкам связано с вербальной составляющей, возможно наиболее полное воплощение культуропростору эпохи. Вокальное искусство как таковое, что является позиционно доступным человечеству и имманентным признаком архетипов украинской ментальности, а также предоставляет возможности через подбор репертуара актуализировать вопрос границ надиндивидуальным, социальным, историческим опытом личностей в определенном поле культуры как определяющего для детерминирования характера деятельности и познания архетипический составляющих в культуротворчих процессах, которые способны носить индивидуально-национальной и общемировой контекст.

Ключевые слова: музыкальный репертуар, вокальное искусство, архетип, украинская ментальность.

Leontieva Sofia, Senior Lecturer, Department of Academic and Pop Vocals, Institute of Arts, Kiev University named after Boris Grinchenko

Vocal art and repertoire in the contemporary cultural space of the era

The purpose of the article is the analysis of the state of vocal art through the prism of the repertoire as a reflection of cultural space, which will help define the concept of the repertoire for determining the social status of the culture of the era. The methodology of research is to apply comparative, historical-logical methods, as well as empirical, general-scientific (analysis, synthesis) methods. Scientific novelty. The article attempts to analyze the present state of vocal art, as well as the features of the repertoire of artists. Separately, the emphasis is put on the formation of a modern repertoire concept. Conclusions. Musical repertoire exists in the space of the corresponding era and is a conceptual image of contemporary events and mood in society. At the same time, it is precise because of vocal art, as being connected with the verbal component, perhaps the most complete embodiment of the cultural space of the era. Vocal art as being positionally accessible to mankind and an inherent feature of the archetypes of Ukrainian mentality, as well as providing opportunities through the selection of the repertoire to actualize the issues between the subindividual, social and historical experience of individuals in a particular field of culture as a determining factor for

(С) Леонтієва С. Л., 2019 
determining the nature of activity and the knowledge of archetypal components in cultural cooking processes that can carry individual, national and global context.

Key words: musical repertoire, vocal art, archetype, Ukrainian mentality.

На етапі сучасного розвитку науки виникає необхідність вивчення вокального мистецтва та проблеми концепту репертуару вокаліста як певного культурогенезу суспільства, що перебуває в контексті соціальних змін. Ці зміни відбуваються в зовнішніх факторах буття та певним чином впливають на створення нових трендів у культуротворчій життєдіяльності особистості музиканта. В умовах відсутності чіткого прогнозування майбутнього культуропростору перед виконавцем стоїть завдання виокремити найбільш успішні вектори для презентації себе перед публікою. Організаційність та концептуальність репертуару в такому контексті стає тим інструментом, який дозволяє відображати та частково передбачати всі сучасні компоненти, моделі та типи соціуму.

У сучасному науковому мистецькому просторі більшість досліджень, які пов'язані з темою вибору репертуару, присвячені вирішенню передусім методичних завдань, а саме комплексному формуванню вокально-технічних і художніх навичок вокаліста ( П. Віардо-Гарсіа, Е. Карузо, М. Донець-Тессеєр, М. Микиша, Л. Дмітрієв, П. Морозов та інш.). Питання формування вокальної культури співаків висвітлювалися в працях українських і китайських авторів: В. Антонюк, Л. Василенко, Н. Гребенюк. Вивчення особливостей сценічної підготовки висвітлено в працях Г. Ципіна, А. Авдієвського. Проте наукові засади модернізації навчального процесу на заняттях 3 вокалу в системі музичної освіти не висвітлюють значення репертуару як відображення сучасних тенденцій в контексті глобалізації саме на концертній естраді. Це й зумовлює актуальність даного дослідження.

В контексті зазначеного основною метою стає висвітлення особливостей вокального мистецтва в контексті формування репертуарного концепту.

Процес ідентифікації особистості вокаліста існує в процесах культурної спільноти як основного провідника глобалізаційних трансформацій. Через уніфікацію зразків масової культури відбувається активізація мистецьких зв'язків цілісного універсального всесвітнього культуропростору. Йдеться про те, що музичне мистецтво, зокрема вокальне, існує як певна компонента, що висвітлює людське світосприйняття в основних світових релігіях, в різних гуманістичних концепціях, тобто відтворює образ єдиного цілісного світу.

Це обгрунтовано доступністю вокального мистецтва для всіх верств населення, його комунікативністю. Комунікативна складова вокального мистецтва виступає як констатація активного процесу формування мистецького простору. Співацька виконавська традиція кожного народу має унікальне національне коріння та формується не тільки в сприятливих умовах, а іноді всупереч їм [2].

Отже, з використанням зв'язків людства 3 традицією співу, з тяжінням будь-якої людини до пісенної комунікації формується певна традиція, яка й дозволяє визначати націю, культуру, епоху. Дозволяє вступати в міжкультурний та міжчасовий діалог, формує комунікативні зв'язки людства в цілому.

Реалізація цієї комунікаційної складової полягає у втіленні музичного матеріалу, яким володіє вокаліст, у певний репертуар. Репертуар в свою чергу залежить від багатьох чинників - від виконавський можливостей, уподобань вокаліста, від типу концерту, вимог публіки, соціально-історичного континууму тощо. Тобто, через публічне виконання вокального репертуару (чи просто співу) іманентно формується загальний творчий концепт наявного часу, репрезентація творчості при асиміляція окремих характеристик творів мистецтва. [7,с.380]. Виконання має публічний характер, де рівень репертуару повинен бути концептуально багатожанровим феноменом, що здатний передати музично-художній образ через уяву співака та реалізацію культурних потреб націїі через здатність до живого перевтілення [6, 38].

Репертуар вокаліста є традиційною ознакою часу, а сьогодні апелює до архетиповості в інтелектуальних здобутках української ментальності. При цьому саме вокаліст в усі часи через репертуар був носієм-репрезентантом найтиповіших рис соціально-історичного континууму. В умовах глобалізації зміни, що відбуваються в мистецтві, імпліцитно тяжіють до нових «форм подання об'єктів та предметів мистецтва як на структурному, так і на змістовому рівнях» [3, 380], і це проявляється передусім у репертуарі музиканта.

На різних етапах вибір репертуару створює особливу філософську концепцію буття, подає усталене відповідно до потреб соціуму світоглядно-диференційоване бачення суспільства. Тобто через репертуар, як ознаку свого часу, зроблено акцент на певні змістові універсалії історичного періоду. Все частіше ми можемо бачити переклад інструментальної музики для вокального ансамблю чи для вокаліста 3 концертмейстером. 
Сьогодні виникає потреба використання всього арсеналу вокальних здібностей та вмінь: класичноакадемічних, естрадних, старовинно-народних вокальних здібностей. Широкий репертуар $є$ ознакою часу, де можна вбачати певну синергію всього, що існує, для виходу на європейську арену та комунікацію на всіх культурних рівнях.

Серед репертуарних складових вокаліста цілком логічно виокремлюються оперні твори, пісні, романси, а сьогодні вже й переклади інструментальної музики. Але найцікавішим $є$ той факт, що сьогодні вокаліст не може дозволити собі спів тільки в одній площині репертуарного буття. В сучасному мистецтві ми все більше стикаємося з необхідністю введення українських зразків вокального мистецтва. Головним у цьому контексті постає не використання вже відомих народних творів, а пошук т а введення в репертуар нових авторських вокальних творів. Саме такий підхід є явищем, іманентно спрямованим на виявлення соціально-історичних та культурно-інтелектуальних здобутків нації.

Сьогодні в умовах глобалізації все більш важливим постає саме необхідність формування національної єдності, яка в умовах трансформаційних змін дає змогу представникам певної країни ідентифікувати себе в межах всесвітнього глобалізованого процесу. Саме цьому сприятиме вокальне мистецтво, яке через концепт репертуару здатне акумулювати складний, «соборний» символ української нації, де традиційний, архетиповий взірець народного твору в сучасній обробці або авторським репертуаром, апелює до європейських середньовічних образів вокаліста «Орфея душ» та втілює сучасні тенденції служіння загальносвітовому соціуму при збереженні глокальної національної складової. Іншими словами, виокремлюється новий образ універсального вокаліста, який дещо синкретично поєднує класичне уявлення про українське мистецтво 3 ідеєю повного оновлення даної мистецької сфери відповідно до світових тенденцій.

Головною умовою існування того чи іншого мистецтва $€$ його внутрішня сутність, що репрезентує потреби соціуму та $є$ відповіддю на попит, який цей соціум і формує.

Сьогодні, незважаючи на швидкоплинність та зміну сфер зацікавленостей, на перший план виходить потреба пошук засобів ідентифікації себе зі світом та себе зі своєю нацією та водночас універсалізація митця як прояв глобалізації людства.

Таке становище цілком логічно відповідає новим соціально-політичним та культурним умовам в Україні. Вокальне мистецтво та репертуар вокаліста в такий спосіб апелює до позицій символу не тільки України, а й скоріше до того, що у О. Лосєва має назву «мистецтво архетипу», яке відображає найвищі здобутки інтелектуалізму цивілізації $[5,198]$. Все це забезпечує динаміку вокального репертуару вокаліста та його вихід на новий змістово-якісний щабель.

Завдяки зацікавленості суспільства вокальним мистецтвом формується концентрат первісного й сучасного мислення. Саме в цьому концентраті можна знайти всі культурні збіги та перетини української та світової ментальності. Отже, музика загальнолюдського рівня отримує нове виконавське рішення саме в звучанні вокалістів у контексті різних репертуарних концепцій.

Яскравим прикладом креативного концепту репертуару у вокальному виконавстві на загальносвітовому рівні (йдеться про популярні й усталені в світовому контексті музичні твори) $€$ виконання вокальним ансамблем інструментального класичного репертуару в аранжуванні.

Таке втілення спрямоване на висвітлення можливостей вокального мистецтва у вирії еволюції концептуальних змін. В основі такого репертуарного та виконавського напрямку $є$ потреба в креативному, сучасному погляді на формування національної ідентичності та відродженні міжсвітових зв'язків. Вокальне мистецтво та концепт такого репертуару постає як універсальний інструмент та засіб, який підходить як для автентичних народних пісень та втілення усталених образів, які несуть суспільноісторичне значення для будь якої нації, так і для створення cover-версії світових хітів та українських творів у сучасному форматі, що робить це цікавим на загальносвітовому рівні. Це не тільки дозволяє ввести українську музику в світовий вокальний обіг, а й формує новий «прототип української людини, яка є традиційно усталеним образом європейського громадянина, який знає та поважає свою історичну пам'ять, але не намагається її виносити на показ, шанує своє минуле та сьогодення» [4].

Отже, сучасний стан культури характеризується феноменами глобалізації, відчуження, пошуку особистісної та культурної ідентифікації, маніпуляції суспільною свідомістю, масовості. Вокальне мистецтво та репертуар існують на рівні ноумена та феномена, й вокальне мистецтво стає прихованою сутністю особистості, яка поєднує в собі й представника сучасного соціуму, й носія мистецьких здібностей, де мистецтво - це сфера, яку можна осягнути в процесі його глибокого вивчення, осмислення, умоглядного споглядання. В свою чергу репертуар набуває рис феномену як такий, що впливає на органи чуття як зовнішній прояв музичної мови у вигляді вербального тексту.

Репертуар в зазначеному контексті повинен базуватися відповідно до можливостей виконавця на таких рівнях, як базовий, класичний (уміння виконувати оперний репертуар) та його осучаснений 
аналог. Сьогодні все частіше ми стикаємося з ситуацією, коли академічна музика потребує певного «полегшення» 3 метою розширення аудиторії. Підготовлену зацікавлену аудиторію змінює глобалізоване суспільство, яке в своїй більшості потребує нових різновидів класичного спадку. Все це гостро актуалізує питання меж впливу надіндивідуального, соціального, історичного досвіду культури як визначального багатовимірного поля детермінування характеру діяльності та пізнання й ролі певних архетипових складових у культуротворчих процесах, які здатні містити індивідуальнонаціональний та загальносвітовий контекст. Це дозволяє по-новому поглянути на народну музику та сприяє поступовому поширенню образу вокаліста та концепту репертуару як унікального й водночас універсального соціального інструменту. В умовах глобалізації сучасного культуропростору виникає новий ракурс розуміння специфіки вокального мистецтва на концептуально новому, якісному, креативному рівні. Сьогоденні реалії дозволяють упевнено стверджувати про наявність інформаціноорієнтаційних та аналітико-креативних можливостей репертуару. Музичне мистецтво вокалу та концепт вокального репертуару стверджується як невід’ємна складова сучасного куьтуропростору, яка, $з$ одного боку, сприяє прагненню до культурної інтеграції (як універсальний інструмент), а 3 іншого прагне до захисту національних пріоритетів та цінностей. Музична рефлексія на процеси глобалізації в галузі репертуару сьогодні виходить на той рівень, коли елітарне класичне мистецтво існує поряд із популярним, зберігаючи іманентно соціальні зв'язки 3 потребами суспільства в глобалізованому середовищі буття.

\section{Jimepamypa}

1. Авдієвський А.Т. Формування особистості на грунті національно-культурного відродження. Мистецтво в школі. Вип. 1. К.: УДПУ, 1996, С. $80-83$.

2. Болдирєв В. О. Народна пісня в репертуарі вокаліста як шлях формування полікультурних виконавських традицій. URL: http://num.kharkiv.ua/share/intermusic/vypusk50/13_\%d0\%91\%d0\%be\%d0\%bb\%d0\%b4\%d0\%b8\%d1\%80 $\% \mathrm{~d} 0 \% \mathrm{~b} 5 \% \mathrm{~d} 0 \% \mathrm{~b} 2 \% 20 \% \mathrm{~d} 0 \% 92 . \% \mathrm{~d} 0 \% 9 \mathrm{e}$. _50_181-192.pdf

3. Каблова Т. Б. Концепт концерту-лекції в умовах глобалізації культури. Національні культури у глобалізованому cвiтi. URL:http://elibrary.kubg.edu.ua/19806/1/Kablova_T_\%D0\%9A\%D0\%9D\%D0\%A3\%D0\%9A\%D0\%86\%D0\%9C_2017.PDF

4. Каблова Т., Тетеря В. Народна пісня як інтенціальна складова у творчості М. Лисенка. Актууальні проблеми історії теориї та практикихудоюсньоїкультури.,URL::.http://library.kubg.edu.ua/17241/1/T_Kablova_V.Teterya_AP_n37_2016\%20(1).PDF

5. Лосев А.Ф. Философия. Мифология. Культура. Москва: Политиздат, 1991. 525 с.

6. Хомутова Л. Г. Створення художнього вокально-сценічного образу. Дніпропетровськ: Пороги, 1995. 150 с. 1994. $373 \mathrm{c}$.

7. Цыпин Г.М. Психология музыкальной деятельности: проблемы, суждения, мнения: Москва: Инрерпракс,

\section{References}

1. Avdeyevsky A. (1996). Formation of personality on the basis of national-cultural revival. Art at school [in Ukrainian].

2. Boldyrev V. (2018). Folk song in the repertoire of the vocalist as a way of forming the multicultural performing traditions. Retrieved from: http://num.kharkiv.ua/share/intermusic/vypusk50/13_\%d0\%91\%d0\%be\%d0\%bb\%d0\%b4\%d0\%b8\%d1\%80\%d0\% b5 \% d0\%b2\%20\%d0\%92.\%d0\%9e._50_181-192.pdf [in Ukrainian].

3. Kablova T. (2017). Concept of a concert-lecture in the conditions of globalization of culture. National Cultures in a Globalized World. Retrieved from: http://elibrary.kubg.edu.ua/19806/1/Kablova_T_ \%D0\%9A\%D0\%9D\%D0\%A3\%D0\% 9A\%D0\%86\%D0\%9C_2017.PDF_[in Ukrainian].

4. Kablova T., Teteriya V. (2016). Folk song as an intentional component in the work of M. Lysenko. Actual problems of history, theory and practice of artistic culture. Retrieved from: URL:: http://elibrary.kubg.edu.ua/17241/1/T_Kablova_V.Teterya_ AP_n37_2016\%20(1).PDF [in Ukrainian].

5. Losev A. (1991). Philosophy. Mythology. Culture [in Russian].

6. Khomutova L. (1995). Creation of artistic vocal-stage image [in Ukrainian].

7. Tsypin G.(1994). Psychology of musical activity: problems, judgments, opinions [in Russian].

Стаття надійила до редакиії 18.09.2019 р. 